\title{
Discipline and Gender: Factors Affecting Graduates’ Salaries
}

\author{
Nitza Davidovitch \\ Ariel University, Ariel, Israel
}

\begin{abstract}
In light of the increased accessibility of higher education, a growing number of students hope to use their studies as a financial springboard. In the current study, we sought to examine whether and to what degree baccalaureate degrees improve graduates' financial situation. In cooperation with Israel's Central Bureau of Statistics we gathered data on 6,091 graduates who completed their studies at the Ariel University Center during 2000-2008. Findings show that graduates earn almost three times the national average salary (and five times the median salary) and indicate employment rates of nearly $100 \%$. The most profitable fields are computer sciences and mathematics, engineering, and architecture. Salaries in the natural and social sciences and in the humanities are significantly lower both compared to the former fields and to the national average salary, at least for this eight year span. The rate of employment among men is $12 \%$ higher than among women and these disparities are found in all disciplines. Research conclusions show that academic degrees per se do not guarantee financial or occupational security. The equation of higher education with a higher income seems to involve other components as well, such as graduates' field of study, job seniority, and field of occupation.
\end{abstract}

Keywords: higher education, financial security, occupational security

\section{Introduction}

The accessibility of higher education, and particularly of baccalaureate degrees, is a major issue for schools of higher education in recent decades (Altbach, Reizberg, \& Rumbley, 2009; Kazis, Vargas, \& Hoffman, 2004; Tierney \& Sagedorn, 2002; Guri-Rosenblit, 2000). Since the first university was established in the 11th century, universities were known as "ivory towers" to which very few were admitted. For centuries, universities maintained an elitist status, preserving social inequality. Universities served as institutions for training social and political elites, and created groups with distinct features. This state of affairs, of higher education as a hegemony of the elite, began to wane 900 years after the first university opened. The end of World War II symbolized a transition to democratic open institutions of higher education. In most Western countries, this process occurred at an accelerated rate throughout the 20th century and led to the massification of baccalaureate degrees. In less than half a century since the end of World War II, student numbers in the majority of Western countries doubled and tripled. In 1950s' Europe, the percentage of undergraduate students ranged from 3\%-5\% of their relevant age group. By the late 1990s, the figure had climbed to $36 \%-53 \%$. Today, it has topped 60\% in most European countries (Lindberg, 2007). In the United States as well, a similar trend is evident with figures reaching nearly $65 \%$ of the relevant population (Lindberg, 2007). Canada (Finnie \& Usher, 2007) and Australia have undergone a similar process, and the number of undergraduate students has exceeded $50 \%$. The number of university students (not including the various colleges) reached $41 \%$ in Finland and 
Portugal in 2005. This was the highest rate. Next came England, France, and the US. In England, the number of university students reached 34\%, in France 33\%, and in the US 30\% (Usher \& Medow, 2010). Israel also has joined this global trend and is part of the global revolution in higher education-in a matter of two decades the number of students has multiplied from 5\% in the early 1990s to 53\% in 2009 (CBS (Central Bureau of Statistics), 2009). In the 2011/2012 academic year, 60\% of Israeli high school graduates proceeded to academic studies (CBS, 2011). In 1990, Israel had 21 schools certified to award academic degrees; these encompassed 88,800 students. By 2011, the number had risen to 66 schools encompassing 297,800 students (CBS, 2011). Admission to undergraduate programs has become widely accessible and most students seeking to attain a baccalaureate degree are able to locate a suitable school for their purposes.

One of the major factors attracting students to the academic world is the perceived potential of accreditation to improve one's status in the labor market and generate financial profit (Ziderman, 1973; Enders, 2010; Furia, Castagna, Mattoscio, \& Scamuffa, 2010). Despite this expectation, the actual state of affairs seems to be more complex. For example, a study held on behalf of the Israeli CHE (Council of Higher Education) described the "over qualification" of employees with baccalaureate degrees (Groot \& van den Brink, 2000; McGuinness \& Bennett, 2007; Davidovitch, Byalsky, Soen, \& Sinuani-Stern, 2013). The researchers claim that at least $37 \%$ of employees occupy jobs that do not require their current level of schooling and as a result, they earn less than people employed in schooling-compatible jobs. The data also suggest that not all degrees are equal—unspecialized Bachelor's degrees increase the risk of not finding a schooling-compatible job. This is particularly evident among graduates of the social sciences, management, general studies, and the humanities. Since pay is the ultimate motivation for higher education and in light of the data on over-qualification in the labor market, our purpose is to expand research-based knowledge on the questions of whether higher education has a monetary value and what is this value? Is there a difference between the wage premiums of university graduates from different disciplines? This issue was examined by the Israeli Central Bureau of Statistics (CBS, 2012a), which found very large earning disparities between graduates of education and the humanities - whose pay was at the bottom of the scale-and graduates of engineering and computer sciences, whose pay headed the scale. Our aim is to explore whether higher education has a monetary value and what is this value? Is there a difference between the wage premiums of university graduates from different disciplines? Does schooling guarantee employment in graduates' relevant discipline? In the current study, we shall seek to answer these and other questions by examining the pay levels of graduates of the Ariel University Center in various disciplines.

\section{Academic Degrees and the Labor Market}

A baccalaureate degree is a prerequisite for many jobs. In the absence of any other information on candidates, academic degrees provide employers with an evaluation of the quality and potential of prospective employees. According to the theory of human capital, employers use credentials for screening, in order to predict employee efficiency and productivity (Tyler, 1982; Taubmann \& Wales, 1975; Burdett, 1978; Cohn, Kiker, \& De Oliveira, 2002). Credentialism refers to the tendency of students and employers to attribute greater significance to the certificate than to the skills themselves (Dore, 1976). This process occurs mainly due to employer belief that schooling "improves" workers and thus, they will be receiving a better return on their money if they employ someone with a more advanced degree. This belief has led employers to demand Bachelor's and Master's degrees of their employees. If employers can employ someone with a graduate degree 
rather than someone with a non-academic diploma they will prefer university graduates-more educated employees for the same pay. In the bureaucratic world, credentials provide information on one's ability to perform tasks in accordance with required bureaucracy (Brown, 2001). Higher education credentials help distinguish between the capable and the incapable and give employers a means of screening and classification (Bills, 1988). According to this approach, having an academic degree guarantees knowledge, skills, loyalty, persistence, and other elements beyond professional knowledge (Brown, 2001). According to this explanation, the market demands academic degrees, perceived as essential for evaluating employees' skills although ultimately not required for the job. Thus, it seems that employers have come to consider academic degrees as a measure of competency, a type of employment asset (Bills, 1988). Employees, from their perspective, believe that degrees increase their opportunity for financial gain, seeing them as a universal ticket to a desirable career, high pay, and a comfortable middle class life. The research supports this claim, whereby higher education is perceived as a way of attaining financial security and protection against poverty (Enders, 2010). From the point of view of potential employees, the higher their degree the larger the probability of attaining a higher income. This view is the ultimate stimulus for acquiring a higher education. However, in light of the drastic rise in the supply of university graduates in the market, and credentialism practiced by employers that enables them to employ more educated graduates for less or at least the same pay, the question is whether academic degrees, of any type, indeed generate monetary gain.

\section{Return on Education}

The subject of returns on higher education has been examined extensively throughout the world. It has been studied recently in Israel as well (for example, Zussman, Forman, Kaplan, \& Romanov, 2007; Frish, 2007a; Navon, 2004; Klinov, 1980). A recent and fairly detailed survey by the Central Bureau of Statistics was published in 2012 and is mentioned above (CBS, 2012a). US research indicates that salary premiums earned by academics are over $40 \%$ higher than those of high school graduates (Card \& Lemieux, 2001). Data for 2011 show that the multiannual average salary of those with a baccalaureate degree is $74 \%$ higher than that of high school graduates. The average salary of employees with graduate degrees is $84 \%$ higher than that of high school graduates (Supiano, 2011). Recent data from the social survey of the CBS also show that in Israel —as elsewhere - there is a high correlation between schooling and income. For example, the last survey shows that in 2010, the monthly income of 56.3\% of those with a minimum of 13 years of schooling was NIS (New Israeli Shekels) 10,001 or more. In contrast, among those with 11-12 years of schooling only $22.2 \%$ reported this level of income (CBS, 2012a). This is a difference of over 250\%! In Japan, massification of higher education was found to lead to a reduced wage premium - and the claim is that this is a consequence of the lower quality of graduates (Hon-Kwong \& Wing, 2005). Salaries affected are mainly those of younger employees and less of more veteran employees. Researchers contend that massification of schooling necessarily leads to an increase in quantity at the expense of quality.

In general, the research literature shows that many variables affect one's level of income and that it is not enough to distinguish between having or not having a degree. For example, Light and Strayer (2004) developed an 11-factor taxonomy indicating causes and reasons of wage disparities within the population of university graduates. Findings indicate that variables such as the type of college from which students graduated, the college where they began their studies (in the case of "transfer students"), the degree (Bachelor, Master, and 
Ph.D.) - all have an effect on the wage premium. Thomas and ZHANG (2005) contended that the quality of the college and the discipline studied are major variables that determine graduates' wage premium. Their research findings show a rise in pay overtime in all disciplines aside from life sciences and history. However, there are more significant pay increases in the disciplines of engineering, business management, and mathematics, than in education, where the rise is relatively small.

Similar data emerge from the CBS survey published in Israel in 2012 (CBS, 2012b). Distinguishing between the sexes, male-favored gender-based salary disparities grow over time. However, ethnic-based disparities were relatively small. Similar findings were also found by Black, Smith, and Daniel (2005) who found that the quality of the school affects graduates' pay, although they claim that this is true for both women and men. A study conducted in Australia found that the quality of the school had no significant effect on graduates’ initial salaries (Birch, Li, \& Miller, 2009).

Discipline was found to have an intermediate effect on pay. Researchers claim that the identity of students' alma mater holds no significance in the Australian labor market. In Britain as well, no significant effect of the school's quality on pay was found one year after graduation (Belfield \& Fielding, 2001). Taniguchi (2005) claimed that the wage premium is related to students' age upon graduation. Specifically, her findings show that US students who graduate at the age of 25 or older have a significantly lower wage premium than those who graduate at a younger age. Interestingly, in Israel the CBS survey found the exact opposite: The wage premium is significantly higher among older than among younger graduates (CBS, 2012b). Taniguchi (2005) also found that the negative impact on pay is more significant for men than for women. She claimed that these differences may stem from the fact that women in general tend to gain less from their higher education with the passage of time (Taniguchi, 2005). Morgan (2008) explored the effect of discipline and gender on wage premium. Findings showed that women, at least in the first year of their career, earn the equivalent of men in professional disciplines such as engineering and the exact sciences. However, the recent CBS survey shows that in Israel the situation is different. Women's pay is significantly lower than men's in all disciplines (CBS, 2012b). Some claim that gender equality is only evident in the first year of one's career and in time men take the lead (Wood, Corcoran, \& Courant, 1993). In other disciplines (social sciences, history, business management, and the humanities), women's salaries were found to be lower than men's. The research claims that these findings show that women are given jobs with lower salaries than men with the same level of skills (Morgan, 2008).

There is no consensus in the research literature on the subject of gender effect, and some claim that the wage premium for schooling is higher for women than for men (Davidovitch et al., 2013), while others claim the opposite (Black et al., 2005; Morgan, 2008; Taniguchi, 2005; Thomas \& ZHANG, 2005; Wood et al., 1993), and yet others contend that there is currently no significant difference between genders (Hubbard, 2011).

Researchers also explored other aspects of baccalaureate degrees and their effect on the wage premium. For example, Hemelt (2010) examined the effect of a double-major versus a single-major degree on one's level of income. Findings show that double-major graduates earn on average a salary that is $3.2 \%$ higher than that of their peers in other majors (after controlling for background variables and type of school). The wage premium of double-major degrees changes according to the combination of majors and particularly lucrative combinations include studying a technical or business subject together with a large variety of other subjects. In one of the most recent studies held in Israel on the returns of higher education, Zussman et al. (2007) found 
that, after controlling for socioeconomic data and intellectual skills, the salary of college graduates on their first job is $20 \%-30 \%$ lower than that of university graduates. Findings also show an extremely high return on higher education in the disciplines of engineering, mathematics, physics, and computer sciences, compatible with very high intellectual skills of students; while in other disciplines salaries for first jobs range from NIS 4,000-6,000 - lower than the national average. Graduates of academic colleges would have earned 8\% more if they had studied at a university due to the level of the school. The monthly wages of university graduates rise over the first three years after graduating by some $20 \%$ among both sexes, while the salary of college graduates was found to rise $5 \%$ less than that of university graduates. The detailed CBS survey showed that the monthly salary of male university graduates had risen by the third year after their graduation to NIS 15,000, up from NIS 10,248 in their last year of studies. This is a rise of $46.4 \%$ while women's salaries rose only $30.3 \%$ over the same period to NIS 8,016, up from 6,150 in their last year of studies. This constitutes a rise of only 30.3\% (CBS, 2012a).

The current study is a continuation of the research conducted by Zussman et al. (2007) with the purpose of examining differences between the various disciplines within the same school—compared to the former research, where the comparison was between colleges and universities. Analyses are based on employment and salary data of graduates of the Ariel University Center as received from the Central Bureau of Statistics.

\section{Findings}

\section{Employment Rates of Graduates}

In the last year of college and subsequently, the proportion of graduates employed rises to about $90 \%$ versus $77 \%$ before beginning their studies. The employment rate of graduates in the different disciplines is not uniform: In the last year of school, about $90 \%$ of graduates of engineering and architecture, economics and management, paramedical professions, and mathematics and computer sciences are employed, versus $75 \%$ in the natural sciences and $82 \%$ in the social sciences and the humanities. Similar discrepancies are evident several years post-graduation as well. The proportion of those employed before beginning their studies and during the years of study is highest in economics and management (85\%-88\%), followed by engineering and architecture and computer sciences and mathematics (72\%-84\%). The lowest proportions are in the natural sciences (54\%-64\%) and paramedical professions (56\%-74\%). The employment rate of male graduates post-graduation is higher than that of female graduates in all disciplines beside economics and management and natural sciences (where the proportions are equal). In engineering and architecture, the discrepancy is about $10 \%$ and in the social sciences and the humanities about $5 \%$. When comparing classes, three years after graduation the proportion of graduates of engineering and architecture and economics and management who were employed remained constant, the proportion of those employed among graduates of social sciences and the humanities is less constant, and discrepancies of 5\% to $9 \%$ may be found between the different classes.

\section{Average Monthly Wages}

In the last year of school, graduates' average monthly pay was NIS 8,394-a rise of 56\% versus the average wage before beginning their studies. By three years post-graduation, the average wage of graduates reached NIS 11,929—a rise of $42 \%$ versus their wages in the last year of school and a rise of $120 \%$ versus their wages before beginning academic studies. Average monthly pay in the last year of school differs greatly between disciplines and ranges from about NIS 4,500 in the natural sciences and social sciences and the humanities to about NIS 10,000 in computer sciences and mathematics and in engineering and architecture. 
Wage discrepancies between disciplines increase with seniority as well. In engineering and architecture, five years post-graduation, graduates' pay rises by $69 \%$ versus their last year of school, while in the social sciences and the humanities graduates' pay rises by only 33\%. When comparing classes, three years post-graduation wages remain stable within all longtime disciplines (engineering and architecture, economics and management, and social sciences and the humanities). There are significant differences between the disciplines in wages before and during academic studies: Before beginning studies, the average monthly pay of students of economics and management is NIS 6,800 versus only NIS 2,100-NIS 2,300 in the natural sciences and paramedical professions. This fact implies a crucial difference in the stage of life at which students commence their studies in the various disciplines.

\section{Discussion}

Higher education has always been associated with myriad benefits: high social status, belonging to a cultural elite, a higher income, and in general, a better future. Until the mid-20th century, these benefits were inaccessible to a majority of the population and only a small proportion could enter what was perceived as an ivory tower. The few who managed to gain access knew that their education would become an asset. In certain periods, while education was not necessarily an economic advantage it was a status symbol and a value in and of itself. With the rise of capitalism and the general shift in the ideology of the Western world, education became an economic tool as well-a way of promising oneself a comfortable and pleasurable life (Wonacott, 2000). At a time when the academic world was not open to the masses, the few who entered could indeed be predicted to number among the higher social classes from a financial perspective as well. However, over the past few decades, the academic world has undergone many transformations, of which the most significant is wide accessibility - massification of the baccalaureate degree. Today most students can find a school in which they will attain a higher education. The consequence is an inflation of baccalaureate degrees. In the current study, we attempted to explore this inflation through the major objective of many students-improving their financial situation. Analysis of the data as a whole shows that in terms of wages and employment rates university graduates are doing very well. In less than 10 years, they reach salaries amounting to nearly three times the average national salary (and five times the median salary) and an employment rate of almost $100 \%$. From this general perspective, academic degrees definitely seem worthwhile. However, a closer look reveals a more complex state of affairs.

\section{Discipline}

Selecting an academic discipline is the most crucial determinant of one's income as well as of one's chances of employment. The findings indicate that the most "profitable" fields are computer sciences, mathematics, engineering, and architecture. In contrast, wages in the natural sciences, social sciences, and the humanities, are significantly lower both than the former and than the national average salary, at least for the first eight years. The discrepancy between the different disciplines remains valid even after acquiring seniority on the job. These findings show that even necessary and socially important professions such as nursing, social work, and psychology, receive less public appreciation —as manifested in salary levels. In contrast, the engineering and architecture professions receive almost immediate recognition in financial terms. One possible explanation is the discrepancy between public funding and private funding-most of the social professions are funded by public organizations, while the engineering and architecture professions are primarily managed by 
private firms. The private market is more profitable than the public market and the first to feel the consequences are government employed academics. These findings are compatible with those of Zussman et al. (2007) who indicated significant discrepancies between the scientific professions and others.

\section{Gender}

One's sex is another significant variable affecting salary levels as well as employment rates. In Israel as elsewhere (Black et al., 2005; Morgan, 2008; Taniguchi, 2005), there are gender discrepancies within the labor market. These are initially evident in the tendency to engage in certain disciplines and to choose fields traditionally considered "feminine", such as social sciences and the humanities-in which women constitute over three quarters of all graduates. In contrast, in professions considered "masculine”, such as engineering and architecture, women constitute one fifth of all graduates. By choosing these fields, women (as well as men) dictate their own future course of earnings, as social sciences and the humanities are not the most profitable fields, as shown above. Thus due to the fundamental differences in women's representation in the profitable fields, there is an integral discrepancy between the sexes in their level of income. This discrepancy is a result not only of inequality between the sexes but also of the public attitude towards social disciplines, which lack financial appreciation. In addition to the inherent discrepancy deriving from selection of a certain track, gender per se constitutes a determinant of male-female disparity as well. This is evident in the disparate employment rate, which is $12 \%$ higher among men. Different rates of employment, despite their changing magnitudes, exist also within each discipline when comparing men and women post-graduation. Although the current study did not examine differences in salary levels between men and women, most studies conducted show that in the majority of Western countries there is some discrepancy in favor of men (Black et al., 2005; Morgan, 2008; Taniguchi, 2005; Thomas \& ZHANG, 2005; Wood et al., 1993). The most recent multi-year CBS study clearly indicates large consistent salary discrepancies between male and female graduates of the various disciplines (CBS, 2012b). This discrepancy, when considered together with those in rates of employment and inherent discrepancies between professions in which women occupy a disproportionately low place, reveal a bleak social state of affairs and a situation of intrinsic inequality.

\section{Conclusions}

Today, when education has become a mass commodity, it seems that an academic degree in and of itself is not enough to guarantee financial or employment security. Employees in the fields of social sciences and the humanities might find themselves earning salaries that equal those of the uneducated. One of the implications that are already in evidence, is the attempt to earn a higher degree on the assumption that it might improve one's financial situation. The equation "more schooling = more money" seems to include other components as well, such as the discipline studied, one's seniority, and the market to which the employee belongs. Students who choose a course of study are in fact choosing their earning capacity. While improving general access to higher education, the massification of higher education has provided large parts of society with a broader range of opportunities than ever, it has also reduced the prestige of the study programs and their related professions. We believe that the salary gaps between the professions reflect society's appreciation and valuation of certain fields, while others are taken for granted. A forward-looking society must reinforce and reward professions that form the core of its existence-educators, caregivers, authors, and philosophers. As things stand now, the message conveyed is that some disciplines are worth much more than others. 


\section{References}

Altbach, P. G., Reizberg, L., \& Rumbley, L. E. (2009). Trends in global higher education: Tracking an academic revolution. Paris: UNESCO.

Belfield, C. R., \& Fielding, A. (2001). Measuring the relationship between resources and outcomes in higher education in the UK. Economics of Education, 20, 589-602.

Bills, D. B. (1988). Credentials and capacities: Employers' perceptions of the acquisition of skills. The Sociological Quarterly, 29(3), 439-449.

Birch, E., Li, I., \& Miller, P. W. (2009). The influences of institution attended and field of study on graduates' starting salaries. Australian Economic Review, 42, 42-63.

Black, D., Smith, J., \& Daniel, K. (2005). College quality and wages in the United States black. German Economic Review, 6, 415-443.

Brown, D. K. (2001). The social sources of educational credentialism: Status cultures, labor markets, and organizations. Sociology of Education, 74 (Extra Issue: Current of Thought: Sociology of Education at the Dawn of the 21st Century), 19-34.

Burdett, K. (1978). The testing and sorting functions of higher education. Journal of Public Economics, 10(1), 117-122.

Card, D., \& Lemieux, T. (2001). Can falling supply explain the rising return to college for younger men? A cohort-based analysis. The Quarterly Journal of Economics, 116, 705-746.

CBS (Central Bureau of Statistics). (2009). Statistical abstract of Israel. Retrieved from http://www.cbs.gov.il/publications/isr_in_n09h.pdf

CBS. (2011). Higher education in Israel-Press release for the occasion of the beginning of the 2011/2012 academic year. Retrieved from http://www.cbs.gov.il/reader/newhodaot/hodaa_template.html?hodaa=201106293

CBS. (2012a). Study course and integration in the workforce of graduates of higher education in Israel 1999-2008 (Annual statistical report, Jerusalem).

CBS. (2012b). The social survey. Retrieved from http://surveys.cbs.gov.il/Survey/survey.htm

Cohn, E., Kiker, B. F., \& De Oliveira, M. M. (2002). Further evidence on the screening hypothesis. Economics Letters, 25(3), 289-294.

Davidovitch, N., Byalsky, M., Soen, D., \& Sinuani-Stern, Z. (2013). The cost of more accessible higher education: What is the monetary value of the various academic degrees? A case study. Contemporary Issues in Education Research Journal, 6(1), 37-58.

Dore, R. (1976). The diploma disease. Berkley and Los Angeles: University of California Press.

Enders, J. (2010). Higher education and the labor market. International Encyclopedia of Education (3rd ed., pp. 365-369). Enschede: University of Twente.

Finnie, R., \& Usher, A. (2007). Room at the top: Strategies for increasing the number of graduate students in Canada. C.D. Howe Institute, 245, 1-25.

Frish, R. (2007a). The economic returns to schooling in Israel. Israel Economic Review, 7(1), 113-141.

Frish, R. (2007b). Economic returns on schooling-The causal relationship between schooling and wages. Jerusalem: Bank of Israel, Department of Research.

Furia, D., Castagna, A., Mattoscio, N., \& Scamuffa, D. (2010). Education and labor market in the age of globalization: Some evidence for EU-27. Procedia-Social and Behavioral Sciences, 9, 1140-1144.

Groot, W., \& Maassen van den Brink, H. (2000). Overeducation in the labor market: A meta-analysis. Economics of Education Review, 19(2), 149-158.

Guri-Rosenblit, S. (2000). Access to higher education: Social perspectives and selection mechanisms. Jerusalem: Van Leer Institute Press.

Hemelt, S. W. (2010). The college double major and subsequent earnings. Education Economics, 18, 167-189.

Hon-Kwong, L., \& Wing, S. (2005). The shrinking earnings premium for university graduates in Hong Kong: The effect of quantity or quality?. Contemporary Economic Policy, 23(2), 242-254.

Hubbard, W. J. (2011). The phantom gender difference in the college wage premium. Journal of Human Resources, 46, 568-586.

Kazis, R., Vargas, J., \& Hoffman, N. (Eds.). (2004). Double the numbers: Increasing postsecondary credentials for underrepresented youth. Cambridge: Harvard Education Press.

Klinov, R. (1980). Income of university graduates. Hariv'on Lekalkala, 27, 243-253. 
Light, A., \& Strayer, W. (2004). Who receives the college wage premium? Assessing the labor market returns to degrees and college transfer patterns. Journal of Human Resources, 39, 746-773.

Lindberg, M. (2007). At the frontier of graduate surveys: Assessing participation and employability of graduates with master's degree in nine European countries. Higher Education: The International Journal of Higher Education and Educational Planning, 53, 623-644.

McGuinness, S., \& Bennett, J. (2007). Overeducation in the graduate labour market: Aquantile regression approach. Economics of Education Review, 26(5), 521-531.

Morgan, L. A. (2008). Major matters: A comparison of the within-major gender pay gap across college majors for early-career graduates. Industrial Relations, 47, 625-650.

Navon, G. (2004). The effect of the heterogeneity of education on wages. Retrieved from http:///www.bankisrael.gov.il/deptdata/mehkar/papers/dp0405h.pdf

Supiano, B. (2011, May). What are you going to do with that?. The Chronicle of Higher Education, 24.

Taniguchi, H. (2005). The influence of age at degree completion on college wage premiums. Research in Higher Education, 46, 861-881.

Taubmann, P., \& Wales, T. (1975). Education as an investment and a screening device. In F. Thomas Juster (Ed.), Education, income and human behavior (pp. 95-122). Retrieved from www.nber.org/chapters/c3694

Thomas, S., \& ZHANG, L. (2005). Post-baccalaureate wage growth within four years of graduation: The effects of college quality and college major. Research in Higher Education, 46, 437-459.

Tierney, W. G., \& Sagedorn, L. S. (Eds.). (2002). Increasing access to college: Extending possibilities for all students. Albany: State University of New York Press.

Tyler, W. (1982). Complexity and control: The organisational background of credentialism. British Journal of Sociology of Education, 3(2), 160-170.

Usher, A., \& Medow, A. (2010). Global higher education rankings 2010: Affordability and accessibility in comparative perspective. Toronto: Higher Education Strategy Associates.

Wonacott, M. E. (2000). Credentials: One size fits all?. Columbus, O.H.: National Dissemination Center for Career and Technical Education.

Wood, R. G., Corcoran, M., \& Courant, P. N. (1993). Pay differences among the highly paid: The male-female earnings gap in lawyers' salaries. Journal of Labor Economics, 11, 417-441.

Ziderman, A. (1973). Does it pay to take a degree? The profitability of private investment in university education in Britain. Oxford Economic Papers, 25(2), 262-274.

Zussman, N., Forman, O., Kaplan, T., \& Romanov, D. (2007). Differences in the quality of education inuniversities and colleges: Examined through job market benefits. Shmuel Ne'eman Institute. Retrieved from http://www.neaman.org.il/Neaman2011/Templates/ShowPage.asp?DBID=1\&TMID=581\&LNGID=2\&FID=646\&IID=7973 